\title{
Exploratory and locomotor activity, learning and memory functions in somatostatin receptor subtype 4 gene-deficient mice in relation to aging and sex
}

\author{
Nikolett Szentes • Valéria Tékus • Violetta Mohos • \\ Éva Borbély • Zsuzsanna Helyes
}

Received: 3 December 2018 / Accepted: 8 March 2019 / Published online: 22 March 2019

(C) The Author(s) 2019

\begin{abstract}
The inhibitory neuropeptide somatostatin regulates several functions in the nervous system including memory. Its concentrations decrease by age leading to functional alterations, but there are little known about the receptorial mechanism. We discovered that somatostatin receptor $4\left(\mathrm{sst}_{4}\right)$ mediates analgesic, anti-depressant, and anti-inflammatory effects without endocrine actions, and it is a unique target for drug development. We investigated the exploratory and locomotor activities and learning and memory functions of male and female sst $_{4}$ gene-deficient mice compared with their wild-types (WT) at ages of 3, 12, 17 months in the Y-maze test, open field test (OFT), radialarm maze (RAM) test and novel object recognition (NOR) test. Young $\mathrm{sst}_{4}$ gene-deficient females visited, repeated, and missed significantly less arms than the WTs in the RAM; males showed decreased exploration in the NOR. Young mice moved significantly more, spend longer time in OFT center, and visited more arms in the Y-maze than older ones. Young WT females spend significantly longer
\end{abstract}

N. Szentes · V. Tékus · É. Borbély $\cdot$ Z. Helyes $(\bowtie)$

Department of Pharmacology and Pharmacotherapy, Faculty of Medicine, János Szentágothai Research Centre \& Centre for

Neuroscience, University of Pécs, Szigeti u. 12, Pécs H-7624, Hungary

e-mail: zsuzsanna.helyes@aok.pte.hu

Z. Helyes

PharmInVivo Ltd., Pécs, Hungary

V. Mohos

Department of Pharmacology, Faculty of Pharmacy, University of Pécs, Pécs, Hungary time in the OFT center, visited, missed and repeated more arms of the RAM than males. Old males found more rewards than females. Young males explored longer the novel object than young females and older males in the NOR; the recognition index was smaller in females. We conclude that aging and sex are important factors of behavioral parameters that should be focused on in such studies. $\mathrm{Sst}_{4}$ is likely to influence locomotion and exploratory behavior only in young mice, but not during normal aging, which is a beneficial feature of a good drug target focusing on the elderly.

Keywords Somatostatin $\cdot \mathrm{sst}_{4}$ receptor Behavior . Exploratory $\cdot$ Memory $\cdot$ Locomotion

\section{Introduction}

Aging strongly influences cognitive functions, memory, and learning. Learning slows down, but memory does not necessarily worsen in the aging population that is continuously increasing in the twenty-first century. Identifying targets for cognitive impairment and memory deficits is in the focus of drug development (Martel et al. 2012). Besides aging, sex is also a crucial factor of cognitive performance (Ruan et al. 2017); therefore, it is important to analyze the differences in preclinical models. It is well established in a variety of species including humans (Vedovelli et al. 2017), rats (Casad 1990; Tenk et al. 2017), and mice (Ashpole et al. 2017; Fang et al. 2017; Reglodi et al. 2018; Spik and Sonntag 1989; Ungvari et al. 2017a) that peptide neurotransmitters, such as 
somatostatin, pituitary adenylate cyclase-activating polypeptide, corticotropin-releasing factor, insulin-like growth factor 1, growth hormone (GH), neurotrophic factor, connective tissue growth factor, play important regulatory roles in age-related diseases, and both their brain and peripheral concentrations change throughout aging.

Somatostatin is a 14 or 28 amino acid-containing peptide with a disulfide bridge discovered in the hypothalamus (Guillemin 1972) and originally described as a GH or somatotropin inhibiting factor (SRIF). Later it was characterized to be a broad spectrum inhibitory neurotransmitter with a complex effect throughout the central nervous system (CNS) (Epelbaum 1986; Martel et al. 2012; Viollet et al. 2008), as well as the periphery to mediate a variety of auto- , para- or endocrine actions (Leblanc et al. 1975; Pintér et al. 2006). Two subpopulations of somatostatinergic neurons can be distinguished in the CNS, long-protruding somatostatinergic neurons and short-proximal glutamate and gamma-aminobutyric acid (GABA)-ergic interneurons (Epelbaum 1986; Gulyás et al. 2003; Tomioka et al. 2005). Somatostatin inhibits the release of several excitatory and inhibitory neurotransmitters, such as serotonin, acetylcholine, glutamate, and GABA (Baraban and Tallent 2004). It plays a role in sensory perception and pain, motor functions, sleep, cognitive performance (Helyes et al. 2009; Matsuoka et al. 1994), and neurodegenerative disorders (Martel et al. 2012; Tuboly and Vecsei 2013), neuroendocrine and emotional regulation, anxiety and depression (Engin et al. 2008; Lin and Sibille 2015). Our team has provided strong proof-of-concept evidence for systemic anti-inflammatory and analgesic effects of somatostatin released from the activated capsaicin-sensitive peptidergic sensory nerves at the periphery called "sensocrine" function (Szolcsányi et al. 2004; Thán et al. 2000).

Brain somatostatin concentrations and its functions are strongly influenced by aging. Early gene expression studies demonstrated a significant reduction of somatostatin mRNA in the striatum, frontal, and parietal cortex, without significant changes in the hypothalamus of female Wistar rats (Florio et al. 1991). Furthermore, hypothalamic somatostatin immunoreactivity significantly decreases in aged female mice (Kuwahara et al. 2004) and rats (Kim and Choe 2018). In the frontal cortex, a certain somatostatinergic neuronal population is remarkably down-regulated (French et al. 2017). Somatostatininduced GH-release inhibition was more sensitive in old animals (Kim and Choe 2018). Moreover, genetic deletion of somatostatin leads to reduced hippocampal neprilysin inactivity and increased $A \beta_{42}$-formation also in young animals, which suggests a potential protective role of somatostatin in the development of Alzheimer's disease and cognitive deficits (Saito et al. 2005). Despite all these data about the expressional and functional alterations of the somatostatinergic systems in the aging brain, very little is known about the regulation, sensitivity, and mechanisms of its receptors (Kim and Choe 2018).

The broad range of actions of somatostatin is mediated by its $5 \mathrm{G}_{\mathrm{i}}$ protein-coupled receptors ( $\mathrm{sst}_{1-5}$ ) categorized into SRIF1 $\left(\mathrm{sst}_{2}, 3,5\right)$ and SRIF2 $\left(\mathrm{sst}_{1,4}\right)$ groups on the basis of synthetic agonist binding potentials (Hoyer et al. 1995). The SRIF2 receptors mediate the endocrine effect of somatostatin, while the SRIF1 ones are responsible for the anti-inflammatory, analgesic, anti-anxiety and antidepressant actions (Prévôt et al. 2017; Scheich et al. 2016, 2017a). We discovered that the $\mathrm{sst}_{4}$ receptor is a very promising target to inhibit neurogenic inflammation, neuropathic pain, and depression (Scheich et al. 2016, 2017b), which was supported by others (Schuelert et al. 2015; Shenoy et al. 2018). Therefore, small molecule sst 4 agonists are potential drug candidates as novel analgesic drugs with simultaneous anti-depressant activity (Botz et al. 2017; Scheich et al. 2016, 2017b). It is very important to elucidate the complex CNS functions of the $\mathrm{sst}_{4}$ receptor from this drug development point of view as well.

Although the precise expression of sst $_{4}$ is not known due to the lack of reliable antibodies, data suggest that it is present in the hippocampus, striatum related to behavior, cognition, and memory (Gastambide et al. 2010; Nakagawasai et al. 2003; Schreff et al. 2000; Viollet et al. 1997), and a small molecule agonist was described to improve long-term and short-term learning in a mouse model of neurodegeneration (Gastambide et al. 2009; Sandoval et al. 2011).

Therefore, in the present study, we investigated the locomotor activity, anxiety, and memory functions in male and female mice throughout aging, as well as the role of the $\mathrm{sst}_{4}$ receptor on these parameters.

\section{Materials and methods}

\section{Animals}

We examined male and female sst $_{4}$ gene-deficient mice (knockout, KO) (Helyes et al. 2009; Scheich et al. 2016, 2017b) and wild-type (WT) counterpart of three different ages (3, 12, 17-month-old) in different behavioral tests. 
They were bred and kept in the Laboratory Animal House of the Department of Pharmacology and Pharmacotherapy of the University of Pécs, Medical School. All animals were in standard plastic cages at $24-25^{\circ} \mathrm{C}$, under a $12-$ $12 \mathrm{~h}$ light-dark cycle and provided by standard rodent chow and water ad libitum.

All experiments were carried out in accordance with the recommendations of the 1998/XXVIII Act of the Hungarian Parliament on Animal Protection (243/1988) and were approved by the Ethics Committee on Animal Research of Pécs University (license no. BA02/2000-76/2017).

\section{Y-maze test}

This test is suitable for rodent memory and route-learning capabilities, where we investigated the exploratory behavior of the mice for new ways (Holcomb et al. 1999; Hullmann et al. 2017). They were placed in the upper arm of the Y-shaped maze, each arm having the same length $(35 \mathrm{~cm})$, width $(5 \mathrm{~cm})$ and height $(6 \mathrm{~cm})$. Mice could freely move within the 5-min-period, the number of visited arms and the alternation index $(\%)(n$ (arm combination $)) /(n($ total number of visited arms- 2$)) \times 100$ were determined.

\section{Radial arm maze (RAM) test}

This test is appropriate for investigating both short-term (working memory) and long-term (reference memory) memory functions (Frick et al. 1999; Gresack and Frick 2003).

It is constructed of eight arms with a well-defined central region where the mice start from. Each arm is $25 \mathrm{~cm}$ long, $7.5 \mathrm{~cm}$ wide, and $6 \mathrm{~cm}$ tall, the central part is $20 \mathrm{~cm}$ in diameter. Four sugar pellets (rewards) were placed in four defined arms, their locations did not change during the experiment. The entire study lasted for 4 days, the measurement time was 5 min every day in the arena. Mice were conditioned on the first 3 days, without and with rewards on the first and second/third days, respectively. The measurement used for evaluation was performed on the fourth day. The test lasted until the animal found all the four sugar pellets, but it was maximized for 5 min (Zhang and O'Donnell 2000). The number of visited, repeated (when the animal reentered a previously visited reward-containing arm), and missed arms (when the animal entered an arm that does not contain rewards), as well as the number of the found rewards and the time to find all the rewards were measured (Astur et al. 2004; Crusio and Schwegler 2005).

We determined the spatial working (the number of repeated arms divided by all visits, then multiplied by 100 ) and reference (the number of missed arms divided by all visits, then multiplied by 100) memory errors.

Novel object recognition (NOR) test

This test was carried out in a $40 \times 40 \mathrm{~cm}$ high-walled box (open-field box) divided into 20 sections and lasted for 3 days. On the first day, the animals are habituated for $5 \mathrm{~min}$, and the test served as an open field test (OFT) when the spontaneous locomotor activity and anxiety (time spent by moving, in the middle and at the periphery) were evaluated (Carola et al. 2002; Gaszner et al. 2012; Scheich et al. 2016). On the second day, two identical objects (smaller than the mouse) were placed in the test area, and the mice were allowed to familiarize with these objects for $5 \mathrm{~min}$. On the third day (after $24 \mathrm{~h}$ ), one object was replaced with a new one of different shape and color, and the animals have observed it for $5 \mathrm{~min}$. We detected how much time the mice spend with the discovery of the familiar and the novel objects; the ratio of which was determined as the recognition index (Antunes and Biala 2012).

All experiments were recorded by the Noldus system and evaluated by the EthoVision XT software.

Statistical evaluation

Data are shown as means \pm SEM, and factorial ANOVA followed by Tukey's HSD post hoc test was used for statistical evaluation. Significant differences were highlighted in all figures as follows: $* p<0.05$, $* * p<0.01, * * * p<0.001$ (related to age; older groups vs. young ones); $\# p<0.05, \# \# p<0.01$, \#\#\# $<0.001$ (relates to sex; females vs. males); $+p<0.05,++p<0.01$, $+++p<0.001$ (related to genotype; KO vs. WT).

\section{Results}

Behavior of male and female $\mathrm{sst}_{4} \mathrm{KO}$ mice of different ages in comparison with respective WT to controls in the Y-maze

Young male and female WT and $\mathrm{sst}_{4}$ gene-deficient mice visited significantly more arms than their older 
counterparts. Furthermore, the 17-month-old female WTs visited significantly less arms compared with males. Deletion of the sst $_{4}$ receptor did not alter the behavior in this test in any age groups either in males or females. There were no significant differences in arm combinations in relation to age, sex, and $\mathrm{sst}_{4}$ receptor deletion (Fig. 1).

$\mathrm{Sst}_{4}$ deficiency and aging worsen the RAM performance of female but not male mice

Young sst $_{4}$ gene-deficient female mice visited, repeated, and missed significantly less arms than the WT counterparts. There was a remarkable sex difference in young mice, females repeated and missed significantly more arms than the males, and also visited more arms, although this parameter was not statistically significant. In the female, but not in the male WT group, young mice visited, repeated and missed more and found significantly more rewards than the respective old ones (Fig. 2).

a

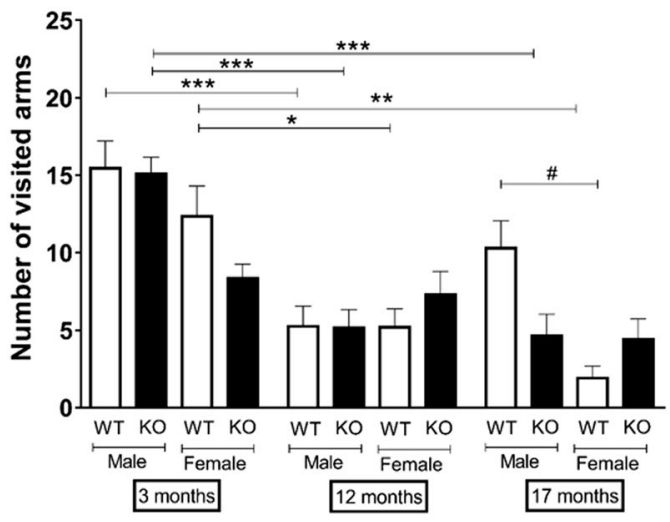

Working and reference memory functions of male and female sst $_{4} \mathrm{KO}$ mice of different ages in comparison with respective WT controls in the RAM

Surprisingly, both aging and $\mathrm{sst}_{4}$ deletion significantly improved the working memory of female but not of male mice. However, the working memory of young and the reference memory of old WT female mice were worse than these functions of age-matched male controls, respectively (Fig. 3).

Aging decreases spontaneous locomotor activity and increases anxiety level in both sexes independently of the $\mathrm{sst}_{4}$ receptor in the OFT

The 12- and 17-month-old mice of both sexes and genotypes moved significantly less during the 5-min measurement, spend less time in the middle and more at the periphery of the OF box than their young controls.

b

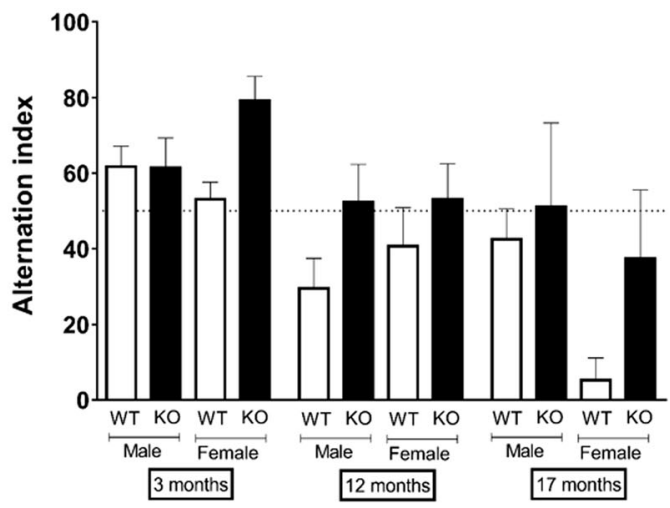

C

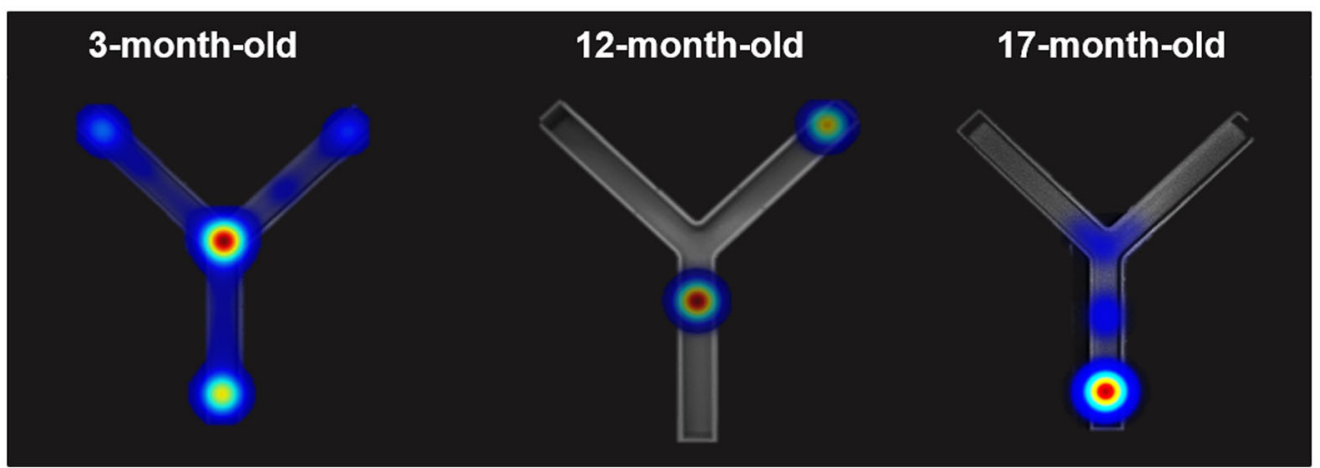

Fig. 1 a The total number of visited arms and $\mathbf{b}$ arm combination in the Y-maze test showing spatial working memory of mice by spontaneous alternation of male and female $\mathrm{sst}_{4}$ gene-deficient mice and WT counterparts of three different ages (3-, 12-, 17- months-old). $\mathbf{c}$ Representative heatmap pictures of male $\mathrm{KO}$ in the three different age groups. Data are means \pm SEM, $* p<0.05$, $* * p<0.01, * * * p<0.001$ (vs. age); $\# p<0.05$ (vs. sex); factorial ANOVA followed by Tukey's HSD post hoc test 
a

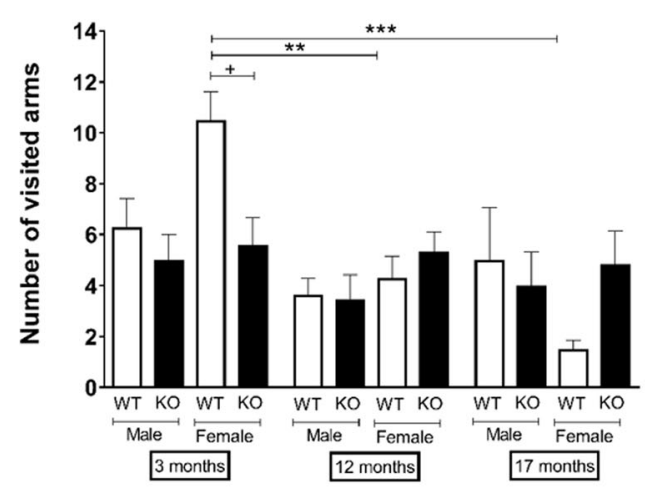

C

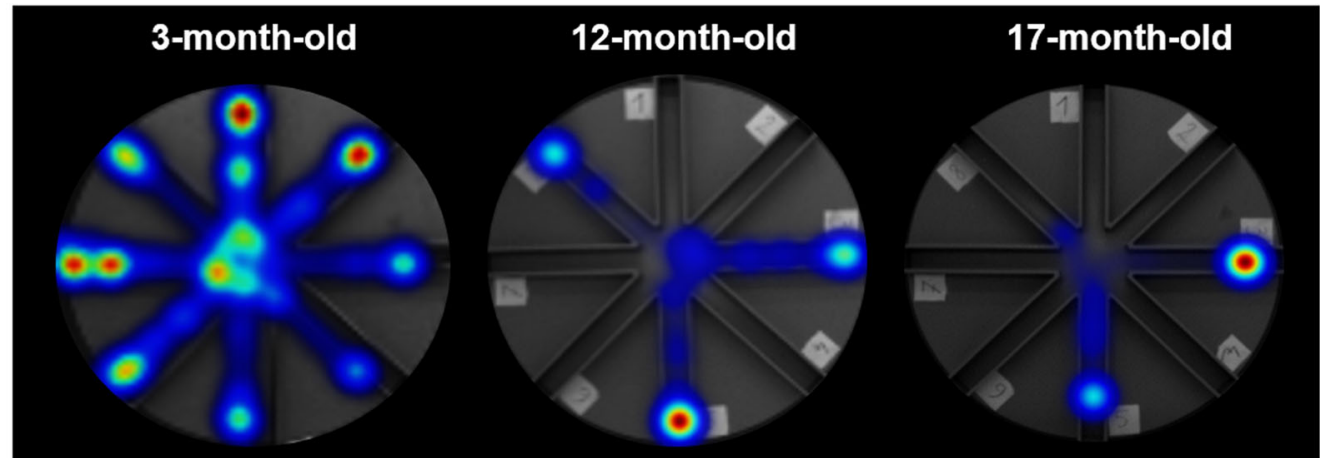

Fig. 2 a The number of visited, $\mathbf{b}$ amount of reward found in the RAM. c Representative heatmap pictures of female WT in the three different age groups. Data are means \pm SEM, ${ }^{* *} p<0.01$,

It is also important to note that in the young WT group, females spend significantly more time in the middle and

a

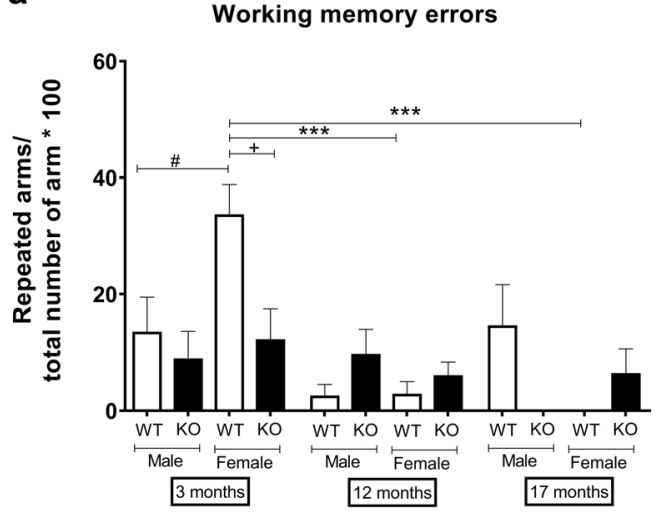

$* * * p<0.001$ (vs. age); $\# p<0.05$ (vs. sex); $+p<0.05$ (vs. gene); factorial ANOVA followed by Tukey's HSD post hoc test b

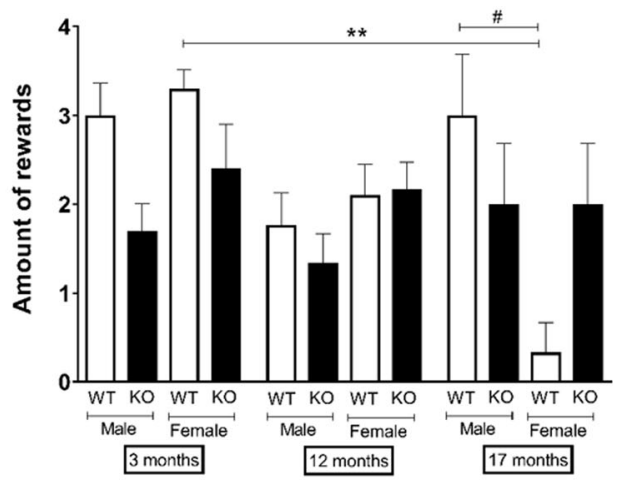

less at the periphery than the age-matched males (Fig. 4). b

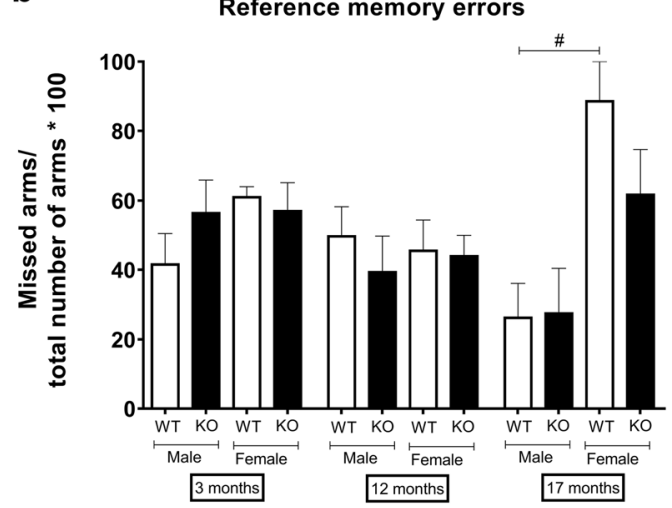

Fig. 3 a Working and $\mathbf{b}$ reference memory functions. Data are means \pm SEM, $* * * p<0.001$ (vs. age); $\# p<0.05$ (vs. sex); $+p<0.05$ (vs. gene); factorial ANOVA followed by Tukey's HSD post hoc test 
a

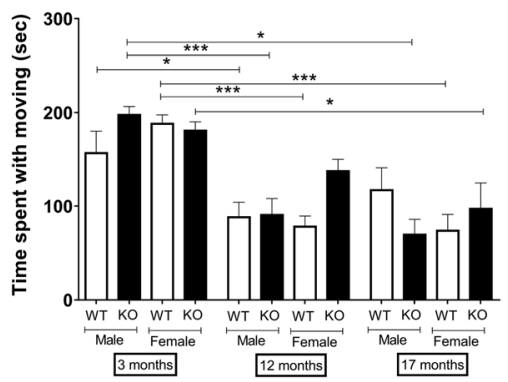

b

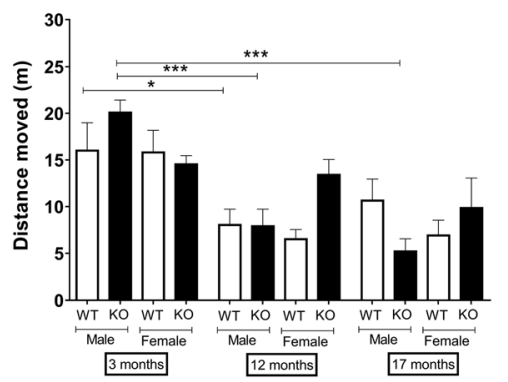

C

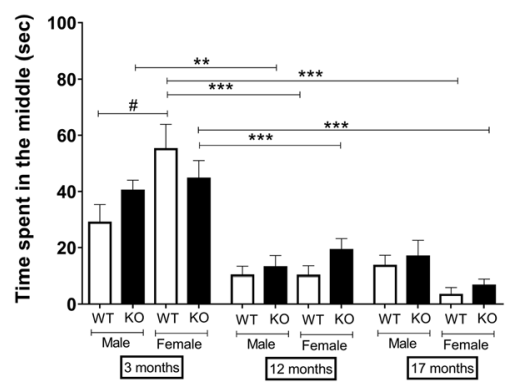

Fig. 4 a Time spend with moving, $\mathbf{b}$ distance moved, and $\mathbf{c}$ time spend in the middle in the open field box. Data are means \pm SEM, $* p<0.05, * * p<0.01, * * * p<0.001$ (vs. age); $\# p<0.05$ (vs. sex); factorial ANOVA followed by Tukey's HSD post hoc test

Decreased exploratory behavior in sst $_{4}$-deficient young male, female and aged mice, but unaltered novelty detection and recognition memory functions in the NOR test

Young WT male mice spend significantly more time with both the familiar and novel objects then the $s_{4} t_{4}$ gene-deficient ones, as well as the female counterparts and old ones both in cases of the first test (day 2) and the repeated test (day 3) (Fig. 5a-d).

The older, 12-, and 17-month-old mice of both sexes and genotypes were much less interested in exploring both objects. The recognition index determined by the ratio of the novel and the familiar object investigations showing the memory function did not show any difference in any groups (Fig. 5e).

\section{Discussion}

We show here that aging and sex are very important factors of behavioral parameters that have to be focused on in such studies. Furthermore, the somatostatin $\mathrm{sst}_{4}$ receptor is likely to be involved in locomotion and exploratory behaviors only in young mice and does not influence behavior during normal aging.

Somatostatin is expressed in brain regions related to pain and mood regulation like the dorsolateral prefrontal, cingulate cortex, and amygdala (Guilloux et al. 2012; Sibille et al. 2011; Tripp et al. 2011). Its important inhibitory functions in several physiological and pathophysiological processes, such as sensory, locomotion and motor coordination (Zeyda et al. 2001), stressrelated and learning activities (Viollet et al. 2008), mood regulation (Engin et al. 2008; Lin and Sibille 2015), cognitive performance, and neurodegeneration (Saito et al. 2005) has also been evidenced in animal models. Furthermore, lower somatostatin levels were measured in the cerebrospinal fluid and the brain areas of patients with major and bipolar depressive disorders, schizophrenia, Alzheimer's, and Parkinson's diseases (Lin and Sibille 2013).

Somatostatin levels strongly decrease in the aging brain to that mRNA and protein levels (Florio et al. 1991; Kuwahara et al. 2004), and its functions are also altered (French et al. 2017; Kim and Choe 2018).

The expression of the $\mathrm{sst}_{4}$ receptor in the brain is similar to that of somatostatin (Martel et al. 2012), but there are no data about its functions and changes in aging. We earlier found enhanced inflammatory and neuropathic hyperalgesia in sst $_{4}$ deleted mice (Helyes et al. 2009). Increased depression-like behaviors and anxiety, as well as altered neuronal activation in the central and basolateral amygdaloid nuclei, were detected in sst $_{4}$ gene-deficient mice upon both acute and chronic stress (Scheich et al. 2017b).

The present results clearly demonstrate that the lack of sst $_{4}$ only influences some behaviors of young mice: females visited, repeated, and missed significantly less arms than the WTs in the RAM, while males showed decreased exploration in the NOR. Since the outcomes of these behavioral tests are greatly modified by the anxiety level of the animals, and the sst $_{4}$-deficient mice have more anxious and depressive-like phenotye (Scheich et al. 2016), our findings might not only be

Fig. 5 a-b Time spend of familiar/familiar object, $\mathbf{c}-\mathbf{d}$ the time of familiar/novel object zone, and e recognition index in the NOR test. f Representative heatmap pictures of male WT in the three different age groups. Data are means \pm SEM, $* * * p<0.001$ (vs. age); \#\#p <0.01, \#\#\#p<0.001 (vs. sex); $+p<0.05$ (vs. gene); factorial ANOVA followed by Tukey's HSD post hoc test 
a

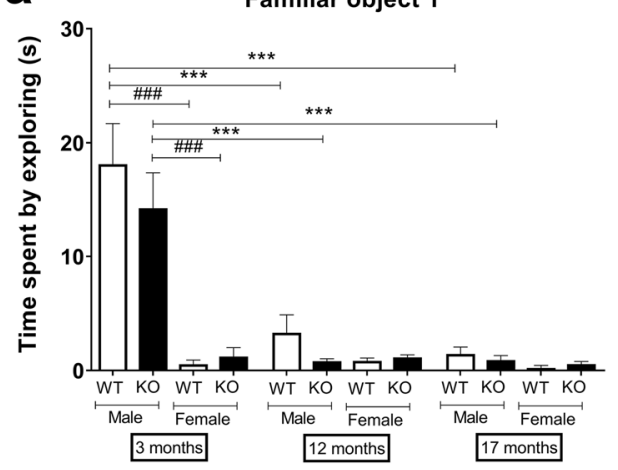

C

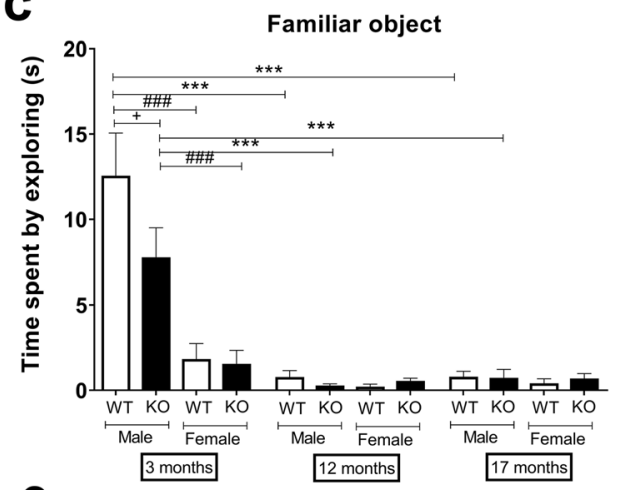

e

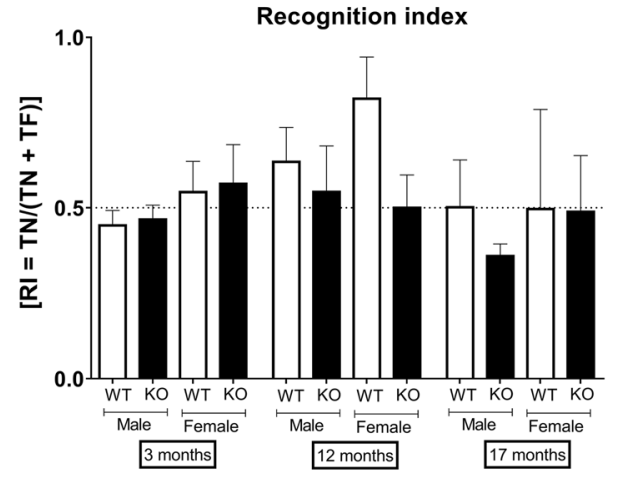

Day 2

Day 3
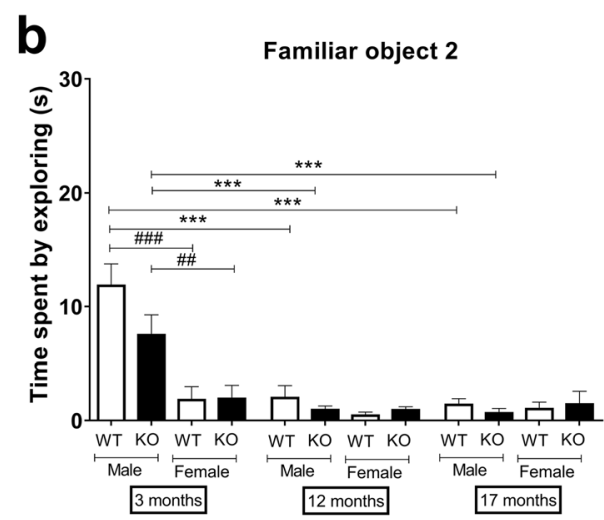

d

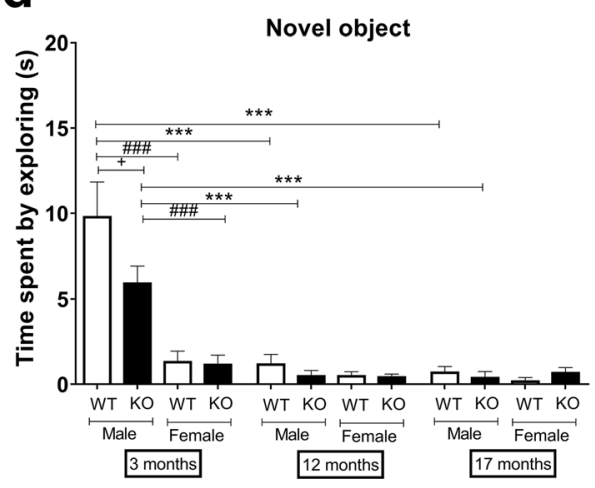

f

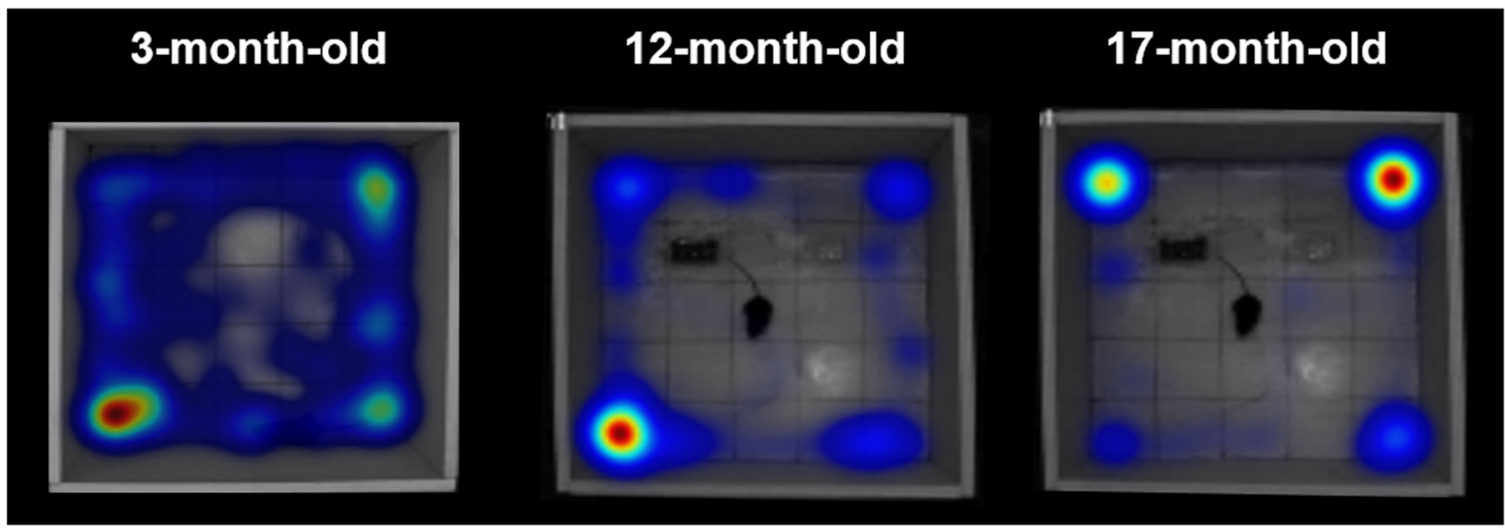


explained by the direct inhibition of learning and locomotion by somatostatin via this receptor, but higher stress level could also be an influencing factor.

Since substantial influence of aging and sex on the behavioral parameters in rodent experiments is wellestablished (Frick et al. 1999; Sutcliffe et al. 2007), we investigated the impact of these factors in our test systems in order to get a complex picture. The OFT (Carola et al. 2002) and the spontaneously alternating Y-maze test are suitable for determining spontaneous locomotor activity, exploratory behavior, and anxiety level (Borbély et al. 2013). Furthermore, the arm combination in the latter test also refers to working memory functions, since the animal has to remember the two arms that visited for the previous time to get the opportunity to choose and create a new alternative (Hughes 2004). Locomotor activity, anxiety, exploration time in both sexes, but working memory of females declined with age. Young males showed worse locomotor activity, higher anxiety, and better recognition memory, but old ones better working memory than females. Young mice moved significantly more, spend longer time in OFT center, and visited more arms in the Y-maze than older ones of both sexes. As for sex differences, we found that young females were more active than males, but the oldest females were less active and anxious than the respective males.

The influence of aging and sex on behavioral and memory parameters was investigated by others earlier with C57BL/6NIA mice. They found deteriorated memory with aging in both sexes up to 25 months in the Morris water maze, elevated plus maze, OFT that are in agreement with our findings. The 17month-old mice showed less exploratory behavior, females had higher anxiety level and better spatial reference memory than males (Frick et al. 1999). Cognitive tests were performed in order to assess spontaneous movement, daily activity, distance moved, velocity, and acceleration in a 90 -h period of time in young and old (C57B1/6J male 6, 21 and 27 months old) mice. Learning abilities and locomotor activity decreased age dependently and similarly to rats and humans. However, memory decline was not observed in all elderly mice (Logan et al. 2018). Furthermore, in a recent study, cognitive decline was investigated in $\mathrm{C} 57 \mathrm{BL} / 6 \mathrm{~J}$ mice in the RAM test after brain irradiation which showed that this test is suitable method for assessing memory function in rodents (Ungvari et al. 2017b).
In both the RAM and NOR tests, the working and recognition memory of young animals were better, respectively. The NOR is widely used to examine memory processes (Bevins and Besheer 2006). Young WT females visited, missed, and repeated more arms of the RAM, but old males found more rewards. In the NOR, young males spend longer time by exploring the novel object than both young females and older males, the recognition index was smaller in females. Similarly to our mouse results here, male rats were shown to perform better in the recognition test (Sutcliffe et al. 2007).

There is a strong proof-of-concept that sst $_{4}$ is a valuable target for the development of analgesic and antidepressant, as well as anti-inflammatory drugs providing a unique tool for the treatment of these common comorbidities particularly in the elderly. Therefore, small molecule sst $_{4}$ agonists with a completely new mechanism of action are under development for chronic neuropathic pain, concomitant mood disorders, and neurogenic inflammation that are still important unmet medical needs (Botz et al. 2017; Pintér et al. 2006; Scheich et al. 2016).

Synthetic $\mathrm{sst}_{4}$ agonists inhibit pain, inflammation (Sándor et al. 2006; Schuelert et al. 2015), depressionlike behavior (Scheich et al. 2016), and as neurodegeneration and cognitive dysfunction via increasing neprilysin activity leading to decreased cortical $A \beta_{1-42}$ formation in rodent models (Sandoval et al. 2011, 2012). We can conclude from the present results, that $\mathrm{Sst}_{4}$ does not influence these functions during normal aging without more severe neuronal damage. Therefore, sst $_{4}$ agonists, as novel drug candidates, are not likely to have a major influence on locomotion and learning ability.

Funding Information Open access funding provided by University of Pécs (PTE). This research was supported by the National Brain Research Program (20017-1.2.1-NKP-2017-00002), 178864/2018/FEKUTSTRAT, GINOP-2.3.2-15-2016-00050 ("PEPSYS Complexity of peptidergic signalization and its role in systemic diseases"), EFOP-3.6.2-16-2017-00008 ("The role of neuroinflammation in neurodegeneration: from molecules to clinics"), EFOP-3.6.1-16-2016-00004, EFOP-3.6.3-VEKOP-16-201700009.

Compliance with ethical standards All experiments were carried out in accordance with the recommendations of the 1998/XXVIII Act of the Hungarian Parliament on Animal Protection (243/1988) and were approved by the Ethics Committee on Animal Research of Pécs University (license no. BA02/2000-76/2017). 
Open Access This article is distributed under the terms of the Creative Commons Attribution 4.0 International License (http:// creativecommons.org/licenses/by/4.0/), which permits unrestricted use, distribution, and reproduction in any medium, provided you give appropriate credit to the original author(s) and the source, provide a link to the Creative Commons license, and indicate if changes were made.

\section{References}

Antunes M, Biala G (2012) The novel object recognition memory: neurobiology, test procedure, and its modifications. Cogn Process 13:93-110

Ashpole NM, Logan S, Yabluchanskiy A, Mitschelen MC, Yan H, Farley JA, Hodges EL, Ungvari Z, Csiszar A, Chen S, Georgescu C, Hubbard GB, Ikeno Y, Sonntag WE (2017) IGF-1 has sexually dimorphic, pleiotropic, and timedependent effects on healthspan, pathology, and lifespan. Geroscience 39:129-145

Astur R, Tropp J, Sava S, Constable RT, Markus EJ (2004) Sex differences and correlations in a virtual Morris water task, a virtual radial arm maze, and mental rotation. Behav Brain Res 151:103-115

Baraban SC, Tallent MK (2004) Interneuron diversity series: Interneuronal neuropeptides - endogenous regulators of neuronal excitability. Trends Neurosci 27:135-142

Bevins RA, Besheer J (2006) Object recognition in rats and mice: a one-trial non-matching-to-sample learning task to study "recognition memory". Nat Protoc 1:1306-1311

Borbély É, Scheich B, Helyes Z (2013) Neuropeptides in learning and memory. Neuropeptides 47:439-450

Botz B, Bölcskei K, Helyes Z (2017) Challenges to develop novel anti-inflammatory and analgesic drugs. Wiley Interdiscip Rev Nanomed Nanobiotechnol 9:1-30

Carola V, D’Olimpio F, Brunamonti E, Mangia F, Renzi P (2002) Evaluation of the elevated plus-maze and open-field tests for the assessment of anxiety-related behaviour in inbred mic. Behav Brain Res 134:49-57

Casad RC (1990) Studies with somatostatin and aging. Dissertation, Jr University of Michigan

Crusio WE, Schwegler H (2005) Learning spatial orientation tasks in the radial-maze and structural variation in the hippocampus in inbred mice. Behav Brain Funct 1:3

Engin E, Stellbrink J, Treit D, Dickson CT (2008) Anxiolytic and antidepressant effects of intracerebroventricularly administered somatostatin: behavioral and neurophysiological evidence. Neuroscience 157:666-676

Epelbaum J (1986) Somatostatin in the central nervous system: physiology and pathological modifications. Prog Neurobiol J Ep 271:63-100

Fang Y, McFadden S, Darcy J, Hill CM, Huber JA, Verhulst S, Kopchick JJ, Miller RA, Sun LY, Bartke A (2017) Differential effects of early-life nutrient restriction in longlived GHR-KO and normal mice. Geroscience 39:347-356

Florio T, Ventra C, Postiglione A, Schettini G (1991) Age-related alterations of somatostatin gene expression in different rat brain areas. Brain Res 557:64-68
French L, Ma TZ, Oh H, Tseng GC, Sibille E (2017) Age-related gene expression in the frontal cortex suggests synaptic function changes in specific inhibitory neuron subtypes. Front Aging Neurosci 9:1-14

Frick KM, Burlingame LA, Arters JA, Berger-Sweeney J (1999) Reference memory, anxiety and estrous cyclicity in C57BL/ 6NIA mice are affected by age and sex. Neuroscience 95 : 293-307

Gastambide F, Viollet C, Lepousez G, Epelbaum J, Guillou JL (2009) Hippocampal SSTR4 somatostatin receptors control the selection of memory strategies. Psychopharmacology 202:153-163. https://doi.org/10.1007/s00213-008-1204-x

Gastambide F, Lepousez G, Viollet C, Loudes C, Epelbaum J, Guillou JL (2010) Cooperation between hippocampal somatostatin receptor subtypes 4 and 2: functional relevance in interactive memory systems. Hippocampus 20:745-757

Gaszner B, Kormos V, Kozicz T, Hashimoto H, Reglodi D, Helyes Z (2012) The behavioral phenotype of pituitary adenylatecyclase activating polypeptide-deficient mice in anxiety and depression tests is accompanied by blunted c-Fos expression in the bed nucleus of the stria terminalis, central projecting Edinger-Westphal nucleus, ventral lateral septum, and dorsal raphe nucleus. Neuroscience 202:283-299

Gresack JE, Frick KM (2003) Male mice exhibit better spatial working and reference memory than females in a waterescape radial arm maze task. Brain Res 982:98-107

Guillemin R (1972) Physiology and chemistry of the hypothalamic releasing factors for gonadotropins: a new approach to fertility control. Contraception 5:1-19

Guilloux J, Douillard-Guilloux G, Kota R, Wang X, Martinowich K, Tseng GC, Lewis DA, Sibille E (2012) Molecular evidence for BDNF- and GABA-related dysfunctions in the amygdala of female subjects with major depression. Mol Psychiatry 17:1130-1142

Gulyás AI, Hájos N, Katona I, Freund TF (2003) Interneurons are the local targets of hippocampal inhibitory cells which project to the medial septum. Eur J Neurosci 17:1861-1872

Helyes Z, Pintér E, Sándor K, Elekes K, Bánvölgyi Á, Keszthelyi D, Szőke É, Tóth DM, Sándor Z, Kereskai L, Pozsgai G, Allen JP, Emson PC, Markovics A, Szolcsányi J (2009) Impaired defense mechanism against inflammation, hyperalgesia, and airway hyperreactivity in somatostatin 4 receptor gene-deleted mice. Proc Natl Acad Sci 106:1308813093

Holcomb LA, Gordon MN, Jantzen P, Hsiao K, Duff K, Morgan D (1999) Behavioral changes in transgenic mice expressing both amyloid precursor protein and presenilin-1 mutations: lack of association with amyloid deposits. Behav Genet 29: 177-185. https://doi.org/10.1023/A:1021691918517

Hoyer D, Bell GI, Berelowitz M, Epelbaum J, Feniuk W, Patel YC, Schonbrunn A, Taylor JE (1995) Classification and nomenclature of somatostatin receptors. Trends Pharmacol Sci 161:86-88

Hughes RN (2004) The value of spontaneous alternation behavior (SAB) as a test of retention in pharmacological investigations of memory. Neurosci Biobehav Rev 28:497-505

Hullmann M, Albrecht C, van Berlo D, Gerlofs-Nijland ME, Wahle T, Boots AW, Krutmann J, Cassee FR, Bayer TA, Schins RPF (2017) Diesel engine exhaust accelerates plaque formation in a mouse model of Alzheimer's disease. Part Fibre Toxicol 14:1-14 
Kim K, Choe HK (2018) Role of hypothalamus in aging and its underlying cellular mechanisms. Mech Ageing Dev 177:7479

Kuwahara S, Kesuma Sari D, Tsukamoto Y, Tanaka S, Sasaki F (2004) Age-related changes in growth hormone (GH)-releasing hormone and somatostatin neurons in the hypothalamus and in GH cells in the anterior pituitary of female mice. Brain Res 1025:113-122

Leblanc H, Anderson JR, Sigel MB, Yen SSC (1975) Inhibitory action of somatostatin on pancreatic $\alpha$ and $\beta$ cell function. $J$ Clin Endocrinol Metab 40:568-572

Lin LC, Sibille E (2013) Reduced brain somatostatin in mood disorders: a common pathophysiological substrate and drug target? Front Pharmacol 4:1-12

Lin LC, Sibille E (2015) Somatostatin, neuronal vulnerability and behavioral emotionality. Mol Psychiatry 20:377-387

Logan S, Owen D, Chen S, Chen WJ, Ungvari Z, Farley J, Csiszar A, Sharpe A, Loos M, Koopmans B, Richardson A, Sonntag WE (2018) Simultaneous assessment of cognitive function, circadian rhythm, and spontaneous activity in aging mice. Geroscience 40:123-137

Martel G, Dutar P, Epelbaum J, Viollet C (2012) Somatostatinergic systems: an update on brain functions in normal and pathological aging. Front Endocrinol (Lausanne) 3:154

Matsuoka N, Maeda N, Yamaguchi I, Satoh M (1994) Possible involvement of brain somatostatin in the memory formation of rats and the cognitive enhancing action of FR121196 in passive avoidance task. Brain Res 642:11-19

Nakagawasai O, Hozumi S, Tan-No K, Niijima F, Arai Y, Yasuhara H, Tadano T (2003) Immunohistochemical fluorescence intensity reduction of brain somatostatin in the impairment of learning and memory-related behaviour induced by olfactory bulbectomy. Behav Brain Res 142:63-67

Pintér E, Helyes Z, Szolcsányi J (2006) Inhibitory effect of somatostatin on inflammation and nociception. Pharmacol Ther 112:440-456

Prévôt TD, Gastambide F, Viollet C, Henkous N, Martel G, Epelbaum J, Béracochéa D, Guillou JL (2017) Roles of hippocampal somatostatin receptor subtypes in stress response and emotionality. Neuropsychopharmacology 42: $1647-1656$

Reglodi D, Atlasz T, Szabo E, Jungling A, Tamas A, Juhasz T, Fulop BD, Bardosi A (2018) PACAP deficiency as a model of aging. Geroscience 40:437-452

Ruan Q, D’Onofrio G, Sancarlo D, Greco A, Lozupone M, Seripa D, Panza F, Yu Z (2017) Emerging biomarkers and screening for cognitive frailty. Aging Clin Exp Res 29:1075-1086

Saito T, Iwata N, Tsubuki S, Takaki Y, Takano J, Huang SM, Suemoto T, Higuchi M, Saido TC (2005) Somatostatin regulates brain amyloid $\beta$ peptide $A \beta 42$ through modulation of proteolytic degradation. Nat Med 11:434-439

Sándor K, Elekes K, Szabó Á, Pintér E, Engström M, Wurster S, Szolcsányi J, Helyes Z (2006) Analgesic effects of the somatostatin sst4 receptor selective agonist J-2156 in acute and chronic pain models. Eur J Pharmacol 539:71-75

Sandoval KE, Farr SA, Banks WA, Niehoff ML, Morley JE, Crider AM, Witt KA (2011) Chronic peripheral administration of somatostatin receptor subtype-4 agonist NNC 269100 enhances learning and memory in SAMP8 mice. Eur J Pharmacol 654:53-59
Sandoval KE, Farr SA, Banks WA, Crider AM, Morley JE, Witt KA (2012) Somatostatin receptor subtype-4 agonist NNC 26-9100 decreases extracellular and intracellular $A \beta 1-42$ trimers. Eur J Pharmacol 683(1-3):116-124

Scheich B, Gaszner B, Kormos V, László K, Ádori C, Borbély É, Hajna Z, Tékus V, Bölcskei K, Ábrahám I, Pintér E, Szolcsányi J, Helyes Z (2016) Somatostatin receptor subtype 4 activation is involved in anxiety and depression-like behavior in mouse models. Neuropharmacology 101:204-215

Scheich B, Cseko K, Borbely E, Abraham I, Csernus V, Gaszner B, Helyes Z (2017a) Higher susceptibility of somatostatin 4 receptor gene-deleted mice to chronic stress-induced behavioral and neuroendocrine alterations. Neuroscience 346:320 336

Scheich B, Vincze P, Szőke É, Borbély É, Hunyady Á, Szolcsányi J, Dénes Á, Környei Z, Gaszner B, Helyes Z (2017b) Chronic stress-induced mechanical hyperalgesia is controlled by capsaicin-sensitive neurones in the mouse. Eur J Pain (United Kingdom) 21:1417-1431

Schreff M, Schulz S, Händel M, Keilhoff G, Braun H, Pereira G, Klutzny M, Schmidt H, Wolf G, Höllt V (2000) Distribution, targeting, and internalization of the sst 4 somatostatin receptor in rat brain. J Neurosci 20:3785-3797

Schuelert N, Just S, Kuelzer R, Corradini L, Gorham LCJ, Doods $\mathrm{H}$ (2015) The somatostatin receptor 4 agonist J-2156 reduces mechanosensitivity of peripheral nerve afferents and spinal neurons in an inflammatory pain model. Eur J Pharmacol 746:274-281

Shenoy PA, Kuo A, Khan N, Gorham L, Nicholson JR, Corradini L, Vetter I, Smith MT (2018) The somatostatin receptor-4 agonist J-2156 alleviates mechanical hypersensitivity in a rat model of breast cancer induced bone pain. Front Pharmacol 9:495

Sibille E, Morris HM, Kota RS, Lewis DA (2011) GABA-related transcripts in the dorsolateral prefrontal cortex in mood disorders. Int J Neuropsychopharmacol 14:721-734

Spik K, Sonntag WE (1989) Increased pituitary response to somatostatin in aging male rats: relationship to somatostatin receptor number and affinity. Neuroendocrinology 50:489494

Sutcliffe JS, Marshall KM, Neill JC (2007) Influence of gender on working and spatial memory in the novel object recognition task in the rat. Behav Brain Res 177:117-125

Szolcsányi J, Pintér E, Helyes Z (2004) Sensocrine function of capsaicin-sensitive nociceptors mediated by somatostatin regulates against inflammation and hyperalgesia. Hyperalgesia: molecular mechanisms and clinical implication. In: Handwerker HO, Brune K (eds) Process in pain research and Mamagement, vol 30. IASP Press, Seattle, pp 113-128

Tenk J, Rostás I, Füredi N, Mikó A, Solymár M, Soós S, Gaszner B, Feller D, Székely M, Pétervári E, Balaskó M (2017) Agerelated changes in central effects of corticotropin-releasing factor (CRF) suggest a role for this mediator in aging anorexia and cachexia. Geroscience 39:61-72

Thán M, Németh J, Szilvássy Z, Pintér E, Helyes Z, Szolcsányi J (2000) Systemic anti-inflammatory effect of somatostatin released from capsaicin-sensitive vagal and sciatic sensory fibres of the rat and Guinea-pig. Eur J Pharmacol 399:251258 
Tomioka R, Okamoto K, Furuta T, Fujiyama F, Iwasato T, Yanagawa Y, Obata K, Kaneko T, Tamamaki N (2005) Demonstration of long-range GABAergic connections distributed throughout the mouse neocortex. Eur J Neurosci 21: $1587-1600$

Tripp A, Kota RS, Lewis DA, Sibille E (2011) Reduced somatostatin in subgenual anterior cingulate cortex in major depression. Neurobiol Dis 42:116-124

Tuboly G, Vecsei L (2013) Somatostatin and cognitive function in neurodegenerative disorders. Mini-Rev Med Chem 13:34- 46

Ungvari Z, Valcarcel-Ares MN, Tarantini S, Yabluchanskiy A, Fülöp GA, Kiss T, Csiszar A (2017a) Connective tissue growth factor (CTGF) in age-related vascular pathologies. Geroscience 39:491-498

Ungvari Z, Tarantini S, Hertelendy P, Valcarcel-Ares MN, Fülöp GA, Logan S, Kiss T, Farkas E, Csiszar A, Yabluchanskiy A (2017b) Cerebromicrovascular dysfunction predicts cognitive decline and gait abnormalities in a mouse model of whole brain irradiation-induced accelerated brain senescence. Geroscience 39:33-42

Vedovelli K, Giacobbo BL, Corrêa MS, Wieck A, de Argimon IIL, Bromberg E (2017) Multimodal physical activity increases brain-derived neurotrophic factor levels and improves cognition in institutionalized older women. Geroscience 39:407417

Viollet C, Bodenant C, Prunotto C, Roosterman D, Schaefer J, Meyerhof W, Epelbaum J, Vaudry H, Leroux P (1997) Differential expression of multiple somatostatin receptors in the rat cerebellum during development. J Neurochem 68: 2263-2272

Viollet C, Lepousez G, Loudes C, Videau C, Simon A, Epelbaum J (2008) Somatostatinergic systems in brain: networks and functions. Mol Cell Endocrinol 286:75-87

Zeyda T, Diehl N, Paylor R, Brennan MB, Hochgeschwender U (2001) Impairment in motor learning of somatostatin null mutant mice. Brain Res 906:107-114

Zhang HT, O'Donnell JM (2000) Effects of rolipram on scopolamine-induced impairment of working and reference memory in the radial-arm maze tests in rats. Psychopharmacology 150:311-316

Publisher's note Springer Nature remains neutral with regard to jurisdictional claims in published maps and institutional affiliations. 